\title{
Two Dimensional Analyses for the Company's Profitability Under the Working Capital Management: Evidence From Egypt
}

\author{
Amira Hasaneen \\ Accounting Department, Faculty of Management \\ Modern University for Technology and Information, Cairo, Egypt \\ E-mail: seven.colours200@gmail.com
}

Received: December 9, 2019

doi:10.5296/ijafr.v10i1.16006
Accepted: January 5, 2020 Published: January 13, 2020

URL: https://doi.org/10.5296/ijafr.v10i1.16006

\begin{abstract}
The current study focused on the impact of working capital management on the financial profitability of Egyptian companies which lasting at EGX according two dimensional analyses; these dimensional are real assets level measured according to "Return on Assets" with financial assets level measured according to "TOBIN Q" during 2011 to 2018 for 23 companies.The study used unbalanced panel data analysis to examining the impact of the working capital management on the profitability. Finally, the study found two dimensional for the impact of working capital management and corporate's profitability; first according to Cost-Benefits analysis at real assets level measured through "Return on Assets"; second according to Risk Return Trade Off at financial assets level measured through "TOBIN Q".
\end{abstract}

Keywords: Working capital management, Return on assets, TOBIN Q, EGX \& Egypt

\section{Introduction}

Working capital management is important to finance which takes considerable time to achieve the perfect balance between profitability and liquidity, and its place in the performance corporate and common stock. The working capital requirement can be specified in accordance by the quantity of funds that a business required to adequately finance operation costs and expenses operation. Companies establish different capital needs, and then no optimal working capital model exists. The main subject of the Working Capital Theory (WCM) is the interaction between current (CA) and existing (CL) assets. 


\section{Ml Macrothink}

International Journal of Accounting and Financial Reporting

ISSN 2162-3082

2020, Vol. 10, No. 1

There is a relationship between companies 'performance on the level of real assets and the performance of their common stock on the level of financial assets. The company's stock is important in the measure where it generates cash flow; the timing of cash flows matters; the money receive is much better as it can be reinvested to produce extra profits or otherwise returned to investor; Thanks to these three realities, managers will raise stock prices for their businesses through improved cash flows and accelerated collection and risk reduction, Working capital management is necessary if a company wants to compete, but sometimes found a conflict between working Capital Terminology like Working capital, sometimes called gross working capital" the current assets used in operations"; Net working capital " current assets minus current liabilities" and Net operating working capital (NOWC) " operating current assets minus operating current liabilities". The company will borrow to purchase the stock, sell the inventory to repay the bank loan, and then restart the process under the principle of working capital management. The definition is extended to more dynamic organizations in which the efficiency of the working capital management of a company was evaluated. Companies usually buy stock, sell goods on loan and receive receivables throughout a period. This process is known as the Cash Conversion Cycle; the working capital strategy aims at reducing the time between product cash spending and sales money accumulation (Brigham and Ehrhardt, 2002).

Under the principle of working capital management, there are many related practices, including the following:
A. Cash Management
B. Inventory Management
C. Receivables Management
D. Accruals and Accounts Payable Management
E. Short-Term Financing

So; the current study are measured the profitability of companies through two levels under Working Capital Management. The study expect find an impact of working capital management on real assets level measured according to "Return on Assets" with financial assets level measured according to "TOBIN -Q".

\section{Literature Review}

Working capital is the corporate's power for conducting the daily operations activities according to consists of the current assets and the current liabilities; efficient working capital management is becoming important for corporates in cases of increased economic uncertainty; so There are multiple studies related to working capital management (WCM), ales the real two main attitudes in the working capital studies, the first for small and medium enterprises (Pais and Gama, 2015; Afrifa and Padachi, 2016; Tran et al., 2017; Afrifa and Tingbani, 2018; Elbadry 2018) and the second one for corporate (Aktas et. al., 2015; Lyngstadaas \& Berg 2016; Kasozi 2017), the method in which working capital is managed will have an impact on the company's profitability. According to Deloof (2003) Managers will increase the 
profitability of companies by reducing the number of accounts receivable days and inventory. More profitable companies are waiting longer for their bills to pay.

The general results indicate that a decrease in the inventories held, in the number of days that firms take to settle their commercial liabilities \& cash conversion cycle, in addition, increase in the number of collect payment days are associated to maximize corporate profitability. Stated Aktas et al., (2015) there an optimal value of working capital. The corporate that converge to that optimal value either through change its investment in working capital \& it's financing in short-term to improve their operating performance. that agree with Small and Medium Enterprises according to Afrifa \& Padachi (2016) under the limited resources of Small and Medium Enterprises, the main focus of managers should be on the set of the specific target value for Working Capital Management so as to increase profitability. That agrees with Mun \& Jang (2015) when the findings ascertain a strong inverted U-shape relationship between working capital and corporate's profitability.

According to Filbeck \& Krueger (2005) there significant differences exist between industries in working capital measures across time. In addition, we discover that these measures for working capital change significantly within industries across time.

Today, the financial thought of working capital management did not stand at objectives of profitability and liquidity; according to Masri \& Abdulla (2018) propose a multiple objective stochastic programming model to select an efficient working capital strategy that takes into consideration not only the conflicting impact of working capital policy on the two firm objectives of liquidity and profitability but also the interrelationships and stochastic aspects of the components of working capital.

In general, working capital policy has an impact on profitability \& liquidity (Singh et. al., 2017); Working capital management \& their policy are a link between operational activities of corporates and macroeconomic changes in cases of boom, recession or crisis; According to Ramiah et al., (2014) the financial crisis has an effect on working capital management practices.

There is another attitude in the working capital studies; it was the determinants of their impact or call control variables such as corporate size (Lyroudi \& McCarty, 1993; Jose et. al., 1996; Moss \& Stine, 1993; Opler et. al., 1999; Ebben \& Johnson, 2011; Shrivastava et. al., 2017). The current study adds other control variables including asset structure, asset management ratios \& debt ratio.

\subsection{Study Layout}

The tremendous changes that have occurred on the stock prices are due to changes in the company's profitability, which are reflection by the practices of working capital management. When company leaders interest efficient resource utilization, we expect these companies to have a stronger and smoother income stream, for example work capital management, which may lead to the creation of added value and at the same time smoother changes in stock price, thus reducing high stock price volatility. 


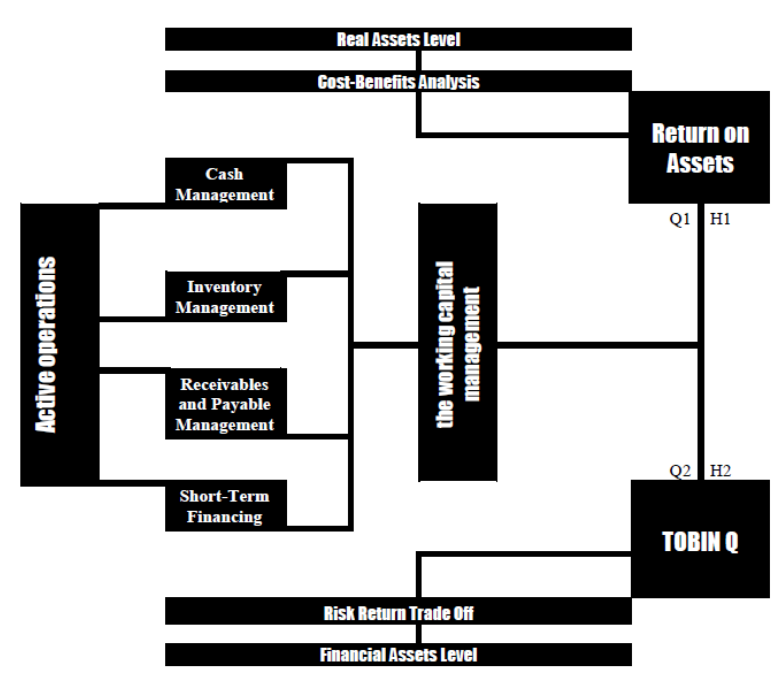

Figure 1. Study layout

The study found two dimensional for the impact of working capital management and corporate's profitability; first according to Cost-Benefits analysis at real assets level measured through "Return on Assets"; second according to Risk Return Trade Off at financial assets level measured through "TOBIN Q"

\subsection{Study Problem}

This study focused on the relationships between working capital management and corporate's profitability as real \& financial asset through analyzing two level of profitability. So, the study has the following questions:

$\mathrm{Q}_{1}$ : Is there an impact of working capital management on return on assets?

$\mathrm{Q}_{2}$ : Is there an impact of working capital management on TOBIN Q?

\subsection{Study Aims}

The study aims to examine the impact of working capital management on the performance of Egyptian companies; the company's performance will be expressed by profitability (Return on Assets) and stockholder's wealth (TOBIN Q).

\subsection{Study Importance}

The study is designed to bridge the gap in literature by presenting empirical evidence of the management of working capital and its effect on exchange listed companies ' quality from a market value on one hand and profitability on other hand. For key stakeholders, such as managers, lenders, financial analysts and bankers, the findings of this study should be of great importance. Good use of the company's assets increases efficiency and reduces uncertainty, reducing the risk of default and therefore increasing the value of the company.

\subsection{Study Hypotheses}

The Study Hypotheses can be formulated as follows: 


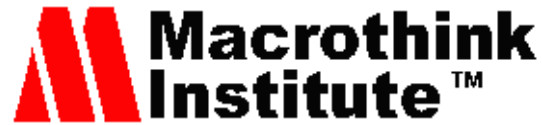

International Journal of Accounting and Financial Reporting ISSN 2162-3082 2020, Vol. 10, No. 1

$\mathrm{H}_{1}$ : There is no significant impact of Working Capital Management (WCM) on Return on Assets (ROA)

$\mathrm{H}_{2}$ : There is no significant impact of Working Capital Management (WCM) on TOBIN Q

\section{Study Methodology}

The study used unbalanced panel data analysis to examining the impact of the working capital management on the profitability according to EViews. The following analyses techniques are descriptive Statistics according to Jarque-Bera test, Unit root test and Tau-statistic Co-integration test.

\subsection{Data Collection}

This study is based on secondary data collection. The data for this study was collected from the audited annual financial report published; the annual data for the listed companies during 2011 to 2018. All data were hand collected from the Egyptian Exchange (EGX) and the annual financial reports of each company. Because of the different existence of their activities, financial institutions and financial companies are excluded from the study. The sample is shown in Table 1.

Table 1. The sample

\begin{tabular}{lll}
\hline No. & COMPANY & ISIN CODE \\
\hline 1 & Abou Kir Fertilizers & EGS38191C010 \\
\hline 2 & ALEXANDRIA CONTAINERS \& GOOD & EGS42111C012 \\
\hline 3 & Arabian Cement Company & EGS3C001C016 \\
\hline 4 & Arabian Cement Company & EGS3C0O1C016 \\
\hline 6 & Cleopatra Hospital Company & EGS729J1C018 \\
\hline 7 & Edita Food Industries S.A.E & EGS305I1C011 \\
\hline 8 & Egypt Aluminum & EGS3E181C010 \\
\hline 9 & Egyptian Chemical Industries (Kima) & EGS38201C017 \\
\hline 10 & Egyptian Financial \& Industrial & EGS38381C017 \\
\hline 11 & EL Ezz Aldekhela Steel - Alexandria & EGS3D041C017 \\
\hline 12 & El Ezz Ceramics \& Porcelain & EGS3C071C015 \\
\hline 13 & Ezz Steel & EGS3C251C013 \\
\hline 14 & GB Auto & EGS673T1C012 \\
\hline 15 & Global Telecom Holding & EGS74081C018 \\
\hline 16 & Ibnsina Pharma & EGS512O1C012 \\
\hline 17 & Juhayna Food Industries & EGS30901C010 \\
\hline 18 & Misr Chemical Industries & EGS38211C016 \\
\hline 19 & Obour Land For Food Industries & EGS30AL1C012 \\
\hline 20 & Oriental Weavers & EGS33041C012 \\
\hline 21 & Paint \& Chemicals Industries (Pachin) & EGS38311C014 \\
\hline 22 & Raya Holding For Technology And Communications & EGS690C1C010 \\
\hline 23 & Sidi Kerir Petrochemicals & EGS380S1C017 \\
\hline & Suez Cement & EGS3C181C012 \\
\hline
\end{tabular}




\subsection{Definition of Variables and Measurements}

The variables were divided into two groups, which are independent, and dependent variables as shown in Tables $2 \& 3$.

Table 2. Dependent variables

\begin{tabular}{lll}
\hline No. & Variable name & Symbols \\
\hline 1 & Return On Assets & Y1 \\
\hline 2 & TOBIN Q & Y2 \\
\hline
\end{tabular}

Table 3. Independent variables

\begin{tabular}{lll}
\hline No. & Variable name & Symbols \\
\hline 1 & Current Ratio & X1 \\
\hline 2 & Quick Ratio & X2 \\
\hline 3 & Cash Ratio & X3 \\
\hline 4 & Working Capital & LNX4 \\
\hline 6 & Net Working Capital & LNX5 \\
\hline 7 & Current Assets to Total Assets & X6 \\
\hline 8 & Total Assets Turnover & X7 \\
\hline 9 & Current Assets turnover & X8 \\
\hline 10 & Fixed Assets Ratio & X9 \\
\hline 11 & Debt Ratio & X10 \\
\hline 12 & LN Sales & X11 \\
\hline 13 & Inventory turnover & X12 \\
\hline 14 & Account Receivables turnover & X13 14 \\
\hline 15 & Account Payable turnover & X15 \\
\hline 16 & Average Inventory Period & X16 \\
\hline 17 & Average Collection Period & X17 \\
\hline 18 & Average Payable Period & X18 \\
\hline 19 & Cash Conversion Cycle & X19 \\
\hline 20 & Operating Cycle &
\end{tabular}

Source: EViews output.

\subsection{Descriptive Statistics}

The study measures the normality distribution of independent and dependent variables indicators according to Jarque-Bera test. 
Table 4. Descriptive statistics for Independent variables

\begin{tabular}{|c|c|c|c|c|c|c|c|c|c|c|}
\hline & $\mathrm{Xl}$ & $\mathrm{x} 2$ & $\mathrm{x} 3$ & LNX4 & LNX5 & $\mathrm{x} 6$ & $\mathrm{X} 7$ & $\mathrm{xs}$ & $\mathrm{Xg}$ & $\mathrm{x} 10$ \\
\hline Mean & 1.822459 & 1.208319 & 0.015873 & 15.91446 & 15.53312 & 0.531856 & 0.501157 & 0.350879 & 0.297247 & 6.955705 \\
\hline Median & 1.538118 & 1.185666 & 0.015533 & 15.63337 & 15.43075 & 0.574212 & 0.459636 & 0.295106 & 0.278950 & 6.822836 \\
\hline Maximum & 3.947204 & 2.433380 & 0.043286 & 18.89245 & 17.94623 & 0.994792 & 1.324901 & 0.887804 & 0.838711 & 8.367822 \\
\hline Minimum & 0.003994 & -0.009081 & 0.000000 & 12.53724 & 12.38587 & 0.001157 & 0.005208 & 0.000000 & 0.000000 & 5.577971 \\
\hline Std. Dev. & 0.982536 & 0.611470 & 0.011713 & 1.429844 & 1.373188 & 0.283674 & 0.333043 & 0.246468 & 0.228709 & 0.609723 \\
\hline Skewness & 0.369542 & 0.202503 & 0.456460 & 0.127310 & -0.221533 & -0.167157 & 0.510903 & 0.459601 & 0.689871 & 0.347236 \\
\hline Kuntosis & 2.506381 & 2.396385 & 2.290915 & 2.573650 & 2.461535 & 1.901047 & 2.544360 & 2.175517 & 2.664322 & 2.970644 \\
\hline Jarque-Bera & 3.521656 & 2.355694 & 5.957336 & 1.099452 & 2.147614 & 5.882613 & 5.580474 & 6.797646 & 8.989646 & 2.154055 \\
\hline \multirow[t]{2}{*}{ Probablity } & 0.171902 & 0.307941 & 0.050861 & 0.577108 & 0.341705 & 0.052797 & 0.061407 & 0.033413 & 0.011167 & 0.340606 \\
\hline & X11 & $\mathrm{X} 12$ & $\mathrm{X} 13$ & X14 & $\mathrm{X} 15$ & $\mathrm{X} 16$ & $\mathrm{X} 17$ & $\mathrm{X} 18$ & X19 & $\mathrm{X} 20$ \\
\hline Mean & 0.613881 & 1.223907 & 5.198274 & 2.819575 & 3.591154 & 100.6954 & 147.3100 & 80.86439 & 180.9688 & 241.8914 \\
\hline Median & 0.616553 & 1.097830 & 3.053131 & 2.287211 & 3.353801 & 74.50319 & 106.2637 & 72.84044 & 153.3441 & 256.1446 \\
\hline Maximum & 1.832266 & 2.759716 & 15.87470 & 7.909852 & 10.02317 & 318.5826 & 412.2196 & 258.4484 & 508.2700 & 441.8324 \\
\hline Minimum & 0.000000 & 0.000000 & 0.348373 & 0.000000 & 0.000000 & 1.230489 & 4.282926 & 0.203205 & -114.8044 & 23.64405 \\
\hline Std. Dev. & 0.433244 & 0.686749 & 4.384389 & 1.928206 & 2.408298 & 79.32289 & 109.4177 & 65.65189 & 120.1547 & 119.5850 \\
\hline Skewness & 0.489317 & 0.365612 & 0.907166 & 0.735994 & 0.490254 & 0.919447 & 0.720865 & 0.913014 & 0.403775 & -0.081040 \\
\hline Kurtosis & 2.761437 & 2.317680 & 2.539945 & 2.924759 & 2.566397 & 2.995908 & 2.545438 & 3.235843 & 2.731393 & 1.708324 \\
\hline Jarque-Bera & 4.523597 & 4.459445 & 15.61954 & 9.685332 & 5.124436 & 15.07607 & 10.18824 & 15.11376 & 3.229109 & 7.555527 \\
\hline Probablity & 0.104163 & 0.107558 & 0.000406 & 0.007886 & 0.077133 & 0.000532 & 0.006133 & 0.000523 & 0.198979 & 0.022874 \\
\hline
\end{tabular}

Source: EViews output.

From Table 4 it can be referred The normality distribution of all Independent indicators by using the Jarque-Bera test at a significant level greater than (0.05) in terms of These Independent variables (Current Ratio, Quick Ratio, Cash Ratio, Working Capital, Net working Capital, Current Assets to Total Assets, Total Assets Turnover, Current Assets turnover, Fixed Assets Ratio, Debt Ratio, Current Liabilities to Total Assets, LN sales, Inventory Turnover, Account receivables Turnover, Account payable Turnover, Average Inventory Period, Average Collection Period, Average Payable Period and Cash Conversion Cycle ) Except (Operating Cycle); it is at a significant level less than (0.05).

Table 5. Descriptive statistics for dependent variables

\begin{tabular}{lll}
\hline & Y1 & Y2 \\
\hline Mean & 5.484075 & 3.147163 \\
\hline Median & 4.693785 & 2.855864 \\
\hline Maximum & 16.35761 & 7.230766 \\
\hline Minimum & -7.380056 & 0.232906 \\
\hline Std.Dev. & 4.859809 & 1.677844 \\
\hline Skewness & 0.228181 & 0.648882 \\
\hline Kurtosis & 2.645510 & 2.695381 \\
\hline Jarque-Bera & 1.488766 & 7.922389 \\
\hline Probability & 0.475027 & 0.019040
\end{tabular}

Source: EViews output. 


\section{Mll Macrothink}

International Journal of Accounting and Financial Reporting

ISSN 2162-3082

2020, Vol. 10, No. 1

From Table 5 it can be referred the normality distribution of Return on Assets by using the Jarque-Bera test at a significant level Greater than (0.05); but (TOBIN Q) because it is at a significant level Less than (0.05).

studies the stationary of time series in order to ensure that the mean and variance are invariant over time according to Unit root test, and the Covariance value between two time periods only depends on the distance between the two periods and not the actual time at which the covariance is computed of the basic all independent and dependent indicators, and this is through the following statistical techniques: Augmented Dickey-Fuller (ADF), Philips-Perrron (PP), Im, Pesaran and Shin W-stat (IPSW), Levin, Lin and Chu t (LLC).

Table 6. Output of unit root test for independent and dependent variables

Group unit root test: Summary: level(0)+individual intercept

Series: X1, X2, X3, LNX4, LNX5, X6, X7, X8, X9, X10, X11, X12, X13, X14, $\mathrm{X} 15, \mathrm{X} 16, \mathrm{X} 17, \mathrm{X} 18, \mathrm{X} 19, \mathrm{X} 20, \mathrm{Y} 1, \mathrm{Y} 2$

Sample: 1107

Exogenous variables: Individual effects

Automatic selection of maximum lags

Automatic lag length selection based on SIC: 0 to 2

Newey-West automatic bandwidth selection and Bartlett kernel

\begin{tabular}{|c|c|c|}
\hline Method & Statistic & Prob.** \\
\hline \multicolumn{3}{|c|}{ Null: Unit root (assumes common unit root process) } \\
\hline Levin, Lin \& Chu t* & -15.9783 & 0.0000 \\
\hline \multicolumn{3}{|c|}{ Null: Unit root (assumes individual unit root process) } \\
\hline Im, Pesaran and Shin W-stat & -17.8441 & 0.0000 \\
\hline ADF - Fisher Chi-square & 416.004 & 0.0000 \\
\hline PP - Fisher Chi-square & 400.427 & 0.0000 \\
\hline
\end{tabular}

Source: EViews output.

From Table 6 it can be referred that: It can be revealed that stationary of the time series of the basic independent and dependent indicators at level zero according to the constant level, and this is through the following statistical techniques: Augmented Dickey-Fuller (ADF), Philips-Perron (PP), Im, Pesaran and Shin W-stat (IPSW), Levin, Lin and Chu t (LLC) at a significant level less than (0.05).

The study measures the existence of long-run equilibrium relationships among no stationary time series variables of basic independent and dependent indicators according to Tau-statistic Co-integration test. 
Table 7. Output of tau-statistic co-integration test

Series: X1 X2 X3 LNX4 LNX5 X6 X7 X8 X9 X10 X11 X12 X13 X14 X15 X16 X17 X18 X19 X20 Y1 Y2

Sample (adjusted): 2107

Included observations: 106 after adjustments

Null hypothesis: Series are not cointegrated

Cointegrating equation deterministics: $\mathrm{C}$

Automatic lags specification based on Schwarz criterion (maxlag=12)

\begin{tabular}{|c|c|c|c|c|}
\hline Variables & tau-statistic & Prob.* & z-statistic & Prob.* \\
\hline $\mathrm{X} 1$ & -7.066169 & 0.0117 & -64.80613 & 0.0204 \\
\hline $\mathrm{X} 2$ & -6.997674 & 0.0140 & -67.71279 & 0.0116 \\
\hline $\mathrm{X} 3$ & -5.618779 & 0.2369 & -49.27628 & 0.2207 \\
\hline LNX4 & -7.505371 & 0.0035 & -73.52171 & 0.0033 \\
\hline LNX5 & -7.268434 & 0.0068 & -69.46200 & 0.0081 \\
\hline X6 & -7.094430 & 0.0109 & -68.39209 & 0.0101 \\
\hline $\mathrm{X} 7$ & -8.255935 & 0.0004 & -82.40364 & 0.0004 \\
\hline $\mathrm{X} 8$ & -7.408222 & 0.0048 & -225.1804 & 0.0000 \\
\hline X9 & -8.794080 & 0.0001 & -131.1580 & 0.0000 \\
\hline X10 & -8.642752 & 0.0001 & -86.34771 & 0.0001 \\
\hline $\mathrm{X} 11$ & -10.87319 & 0.0000 & -111.5282 & 0.0000 \\
\hline $\mathrm{X} 12$ & -8.315358 & 0.0003 & -83.06658 & 0.0003 \\
\hline $\mathrm{X} 13$ & -7.836533 & 0.0013 & -78.16465 & 0.0011 \\
\hline X14 & -7.849060 & 0.0013 & -80.37911 & 0.0006 \\
\hline $\mathrm{X} 15$ & -7.377415 & 0.0051 & -71.01750 & 0.0058 \\
\hline X16 & -7.356417 & 0.0054 & -72.21619 & 0.0045 \\
\hline $\mathrm{X} 17$ & -7.857948 & 0.0012 & -77.76871 & 0.0012 \\
\hline X18 & -7.946138 & 0.0009 & -79.68420 & 0.0008 \\
\hline X19 & -8.727970 & 0.0001 & -154.9325 & 0.0000 \\
\hline $\mathrm{X} 20$ & -7.549889 & 0.0031 & -74.66098 & 0.0026 \\
\hline Y1 & -7.302436 & 0.0062 & -70.89546 & 0.0060 \\
\hline $\mathrm{Y} 2$ & -6.128491 & 0.0989 & -55.90859 & 0.0915 \\
\hline
\end{tabular}

Source: EViews output.

From Table 7 it can be referred that :It can be revealed that there are long-term equilibrium relationships among the basic Independent and Dependent indicators, according to the Tau-statistic, Z-statistic criteria at a significant level less than (0.05) Except The Variables 


\section{MlMacrothink}

International Journal of Accounting and Financial Reporting

ISSN 2162-3082

(Cash Ratio and TOBIN Q) Because of the Tau-statistic, Z-statistic criteria at a significant level greater than (0.05).

\section{Examining the Impact of the Working Capital Management on ROA}

In next table can show the Output of Kao Residual Cointegration Test for Return on Assets

Table 8. The output of Kao residual Cointegration test for return on assets

Kao Residual Cointegration Test

Series: Y1 X1 X2 X3 LNX4 LNX5 X6 X7 X8 X9 X10 X11 X12 X13 X14 X15 X16 X17 X18 X19 X20

Sample: 20112018

Included observations: 107

Null Hypothesis: No cointegration

Trend assumption: No deterministic trend

User-specified lag length: 1

Newey-West automatic bandwidth selection and Bartlett kernel

t-Statistic Prob.

$\begin{array}{lll}\mathrm{ADF} & -3.670435 \quad 0.0001\end{array}$

Residual variance

11.08698

HAC variance

7.441133

Source: EViews output.

According to Kao Residual Cointegration Test for Gross Profit Margin, the study can be revealed that there are long-term equilibrium relationships among Working Capital Management (WCM) and Return on Assets at a significant level less than (0.05). In next table can show the Output of Redundant Fixed Effects Tests for Return on Assets 
Table 9. Output of panel least squares for return on assets

\begin{tabular}{|c|c|c|c|}
\hline \multicolumn{4}{|c|}{ Dependent Variable: Y1 } \\
\hline \multicolumn{4}{|c|}{ Method: Panel Least Squares } \\
\hline \multicolumn{4}{|l|}{ Sample: 20112018} \\
\hline \multicolumn{4}{|l|}{ Periods included: 8} \\
\hline \multicolumn{4}{|c|}{ Cross-sections included: 23} \\
\hline \multicolumn{4}{|c|}{ Total panel (unbalanced) observations: 107} \\
\hline \multicolumn{4}{|c|}{ White cross-section standard errors \& covariance (d.f. corrected) } \\
\hline Variable & Coefficient & Std. Error t-Statistic & Prob. \\
\hline $\mathrm{X} 2$ & 0.966689 & $0.485933 \quad 1.989348$ & 0.0504 \\
\hline $\mathrm{X7}$ & 2.073051 & $1.108524 \quad 1.870100$ & 0.0655 \\
\hline $\mathrm{X} 11$ & 6.945821 & $1.749681 \quad 3.969765$ & 0.0002 \\
\hline $\mathrm{X} 12$ & -2.235380 & $0.910006 \quad-2.456445$ & 0.0164 \\
\hline $\mathrm{C}$ & 1.749070 & $0.865846 \quad 2.020070$ & 0.0470 \\
\hline \multicolumn{4}{|c|}{ Effects Specification } \\
\hline \multicolumn{4}{|c|}{ Cross-section fixed (dummy variables) } \\
\hline \multicolumn{4}{|c|}{ Period fixed (dummy variables) } \\
\hline R-squared & 0.783107 & Mean dependent var & 5.484075 \\
\hline Adjusted R-squared & 0.685060 & S.D. dependent var & 4.859809 \\
\hline S.E. of regression & 2.727302 & Akaike info criterion & 5.097647 \\
\hline Sum squared resid & 542.9868 & Schwarz criterion & 5.946957 \\
\hline Log-likelihood & -238.7241 & Hannan-Quinn criteria. & 5.441946 \\
\hline F-statistic & 7.987029 & Durbin-Watson stat & 1.965134 \\
\hline Prob(F-statistic) & 0.000000 & & \\
\hline
\end{tabular}

Source: EViews output.

According to panel estimation model using least squares, it can be concluded that The Variables of Working Capital Management (WCM) were accepted in the model (Quick Ratio, Total Assets turnover, Current Liabilities to Total Assets and LN Sales) explain (78.3\% ) from total variation of Return on Assets ( ROA), and the rest percent due to either the random error in the regression model or other Variables of Working Capital Management (WCM) excluded from regression model.

$\mathrm{F}$ test is a test to determine if there is a linear relationship between Return on Assets and a subset of Working Capital Management Variables. Since the value of "F test" is (7.98) with significant at the (.001) level, then the researcher concludes that the Variables of Working Capital Management (WCM) were accepted in the model have been affected on the level of Return on Assets.

It would be useful to determine the significant value of each of The Variables of Working Capital Management coefficient in the regression model. The most significant The Variables of Working Capital Management (WCM) were accepted in the model are Quick Ratio, Total 


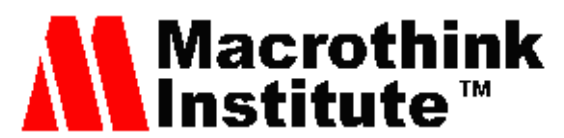

International Journal of Accounting and Financial Reporting

ISSN 2162-3082

2020, Vol. 10, No. 1

Assets turnover, Current Liabilities to Total Assets and LN Sales with the significant level at less than (0.05).

Since the significance value of the test statistic $(\geq 0.05)$; $(0.100016)$, then we would not reject the null hypothesis (H0): Errors are normally distributed, and we conclude that the observed distribution corresponds to or equal the theoretical distribution, i.e. the observed errors are normally distributed.

\section{Examining the Impact of the Working Capital Management on TOBIN Q}

In next table can show the Output of Kao Residual Cointegration Test for TOBIN Q

Table 10. The output of Kao residual Cointegration test for TOBIN Q

Kao Residual Cointegration Test

Series: Y2 X1 X2 X3 LNX4 LNX5 X6 X7 X8 X9 X10 X11 X12 X13 X14 X15 X16 $\mathrm{X} 17 \mathrm{X} 18 \mathrm{X} 19 \mathrm{X} 20$

Sample: 20112018

Included observations: 107

Null Hypothesis: No cointegration

Trend assumption: No deterministic trend

User-specified lag length: 1

Newey-West automatic bandwidth selection and Bartlett kernel

t-Statistic Prob.

ADF $\quad-2.996613 \quad 0.0014$

Residual variance

0.765279

HAC variance

0.672808

Source: EViews output.

According to Kao Residual Cointegration Test for Gross Profit Margin, the study can be revealed that there are long-term equilibrium relationships among Working Capital Management (WCM) and TOBIN_Q (Y2) at a significant level less than (0.05). 
Table 11. Output of panel least squares for TOBIN Q

\begin{tabular}{|c|c|c|c|c|}
\hline \multicolumn{5}{|c|}{ Dependent Variable: Y2 } \\
\hline \multicolumn{5}{|c|}{ Method: Panel Least Squares } \\
\hline \multicolumn{5}{|c|}{ Sample (adjusted): 20122018} \\
\hline \multicolumn{5}{|l|}{ Periods included: 7} \\
\hline \multicolumn{5}{|c|}{ Cross-sections included: 23} \\
\hline \multicolumn{5}{|c|}{ Total panel (unbalanced) observations: 84} \\
\hline \multicolumn{5}{|c|}{ White cross-section standard errors \& covariance (d.f. corrected) } \\
\hline Variable & Coefficient & Std. Error & t-Statistic & Prob. \\
\hline Y2(-1) & 0.255940 & 0.160664 & 1.593008 & 0.1173 \\
\hline $\mathrm{X} 1$ & -0.466287 & 0.170214 & -2.739412 & 0.0085 \\
\hline $\mathrm{X} 3$ & 39.95494 & 20.31369 & 1.966898 & 0.0546 \\
\hline X6 & 3.312081 & 0.891801 & 3.713923 & 0.0005 \\
\hline $\mathrm{C}$ & 0.708532 & 0.504740 & 1.403756 & 0.1665 \\
\hline \multicolumn{5}{|c|}{ Effects Specification } \\
\hline \multicolumn{5}{|c|}{ Cross-section fixed (dummy variables) } \\
\hline \multicolumn{5}{|c|}{ Period fixed (dummy variables) } \\
\hline R-squared & 0.829542 & Mean c & endent var & 3.119675 \\
\hline Adjusted R-squared & 0.722588 & S.D. de & ndent var & 1.671265 \\
\hline S.E. of regression & 0.880254 & Akaike & fo criterion & 2.869511 \\
\hline Sum squared resid & 39.51723 & Schwal & criterion & 3.824475 \\
\hline Log-likelihood & -87.51948 & Hannar & Quinn criteria. & 3.253399 \\
\hline F-statistic & 7.756051 & Durbin & Jatson stat & 1.734561 \\
\hline $\operatorname{Prob}($ F-statistic $)$ & 0.000000 & & & \\
\hline
\end{tabular}

Source: EViews output.

The Variables of Working Capital Management (WCM) were accepted in the model (Current Ratio, Cash Ratio and Current Assets to Total Assets) explain (82.95\% ) from total variation of dependent variable (TOBIN Q), and the rest percent due to either the random error in the regression model or other The Variables of Working Capital Management (WCM) excluded from regression model.

$\mathrm{F}$ test is a test to determine if there is a linear relationship between TOBIN Q and a subset of the Variables of Working Capital Management (WCM). Since the value of "F test" is (7.75) with significant at the (.001) level, then the researcher concludes that the Variables of Working Capital Management (WCM) were accepted in the model have been affected on the level of TOBIN Q

According to t-test; it would be useful to determine the significant value of each of the individual The Variables of Working Capital Management (WCM) coefficient in the regression model. The most significant The Variables of Working Capital Management (WCM) were accepted in the model are Current Ratio, Cash Ratio and Current Assets to Total Assets with the significant level at less than (0.05). 
According to The Jarque-Bera Test; Since the significance value of the test statistic not $(<0.001)$; $(0.001)$, then we would reject the null hypothesis $(\mathrm{H} 0)$ : Errors are normally distributed, and we conclude that the observed distribution corresponds to or equal the theoretical distribution, i.e. the observed errors are not normally distributed.

So; the study has an Evidence from Egyptians companies for impact of Working Capital Management (WCM) on TOBIN Q; the sources this impact from Current Ratio, Cash Ratio and Current Assets to Total Assets \& this impact has explain (82.9\%) from total variation of TOBIN Q.

\section{Discussion and Conclusions}

Efficient use of resources and funding sources contributes to the value creation. In the current study, the effect of working capital management on the performance; According two dimensional analyses; these dimensional are real assets level measured according to "Return on Assets" with financial assets level measured according to "TOBIN Q"; in one emerging market was empirically investigated. The study also speculated the rise in the productivity of working capital management. With the use of a sample of 23 companies on the Egyptian Exchange for the 2011-2018 period,

the study has an Evidence from Egyptians companies for impact of Working Capital Management (WCM) on TOBIN Q; the sources this impact from Current Ratio, Cash Ratio and Current Assets to Total Assets \& this impact has explain (82.9\%) from total variation of TOBIN Q; this conclusion agree with Mohamad and Saad; 2010 and Eldomiaty et. al.,2016. In addition to impacting the profitability of companies this conclusion agree with Shin and Soenen; 1998, Lazaridis and Tryfonidis; 2006; Raheman and Nasr; 2007, Mohamad and Saad; 2010 and Singh et al., 2017.

There is a correlation between the investing at working capital on one hand with production facilities on other hand; if the company's working capital is small, it will lose most good odds of investment and suffer from major liquidity shortages. This effectively utilizes work resources and displays the advantages of flexibility, solvability, productivity, competitiveness and asset maximization of investors. If the managers conduct the cash conversion process and optimize the accounts receivables, they make good profits for the company. The managers increase the shareholder's value and make high profits.

According to Panda and Nanda (2018) that convex relationship between working capital financing and company's profitability; this conclusion agree with study layout for real assets level; but according to Mulyono et al. (2018) Companies must maintain the sustainability of their business. The profitability of many Companies fluctuates and tends to decrease every year. One of the causes is inefficient working capital management.

According to Pirttilä et al. (2019); company's operating with efficient Working Capital Management models are typically the pioneers and the most dominant on-screen characters in the store network. Further, the most productive firms are those that pay their providers expeditiously. On other hand that different WCM models are applied within the supply chain, and many companies reduced their current assets (Lind et al., 2019). So the study found 


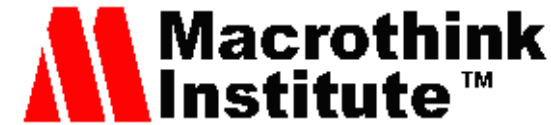

International Journal of Accounting and Financial Reporting

ISSN 2162-3082

Knowledge gap at efficient working capital management, the study recommend that it be the field of future research.

Finally; The study found two dimensional for the impact of working capital management and corporate's profitability; first according to Cost-Benefits analysis at real assets level measured through "Return on Assets"; second according to Risk Return Trade Off at financial assets level measured through "TOBIN Q".

\section{References}

Afrifa, G. A., \& Padachi, K. (2016). Working capital level influence on SME profitability. Journal of Small Business and Enterprise Development, 23(1), 44-63.

Afrifa, G., \& Tingbani, I. (2018). Working capital management, cash flow and SMEs' performance. International Journal Banking, Accounting and Finance, 9(1).

Aktas, N., Croci, E., \& Petmezas, D. (2015). Is working capital management value-enhancing? Evidence from firm performance and investments. Journal of Corporate Finance, 30, 98-113.

Brigham, E. F., \& Ehrhardt, M. C. (2002). Financial management: theory and practice (10th ed.). Melbourne: Thomson Learning.

Deloof, M. (2003). Does working capital management affect profitability of Belgian firms?. Journal of Business Finance \& Accounting, 30(3\&4), 573-588.

Ebben, J. J., \& Johnson, A. C. (2011). Cash conversion cycle management in small firms: Relationships with liquidity, invested capital, and firm performance. Journal of Small Business \& Entrepreneurship, 24(3), 381-396.

Elbadry, A. (2018). The determinants of working capital management in the Egyptian SMEs. Accounting and Finance Research, 7(2), 155.

Eldomiaty, T. I., Rashwan, M. H., Bahaa El Din, M., \& Tayel, W. (2016). Firm, industry and economic determinants of working capital at risk. International Journal of Financial Engineering, 3(04), 1650031.

Filbeck, G., \& Krueger, T. M. (2005). An analysis of working capital management results across industries. American Journal of Business, 20(2), 11-20.

Jose, M. L., Lancaster, C., \& Stevens, J. L. (1996). Corporate returns and cash conversion cycles. Journal of Economics and Finance, 20(1), 33.

Kasozi, J. (2017). The effect of working capital management on profitability: a case of listed manufacturing firms in South Africa. Investment Management and Financial Innovations, 14(2), 336-346.

Lazaridis, I., \& Tryfonidis, D. (2006). The Relationship between Working Capital Management and Profitability of Listed Companies in the Athens Stock Exchange. Journal of Financial Management and Analysis, 19(1), 26-35. 


\section{MlMacrothink}

International Journal of Accounting and Financial Reporting

ISSN 2162-3082 2020, Vol. 10, No. 1

Lind, L., Monto, S., \& Kärri, T. (2019). Mapping working capital models in the automotive industry. International Journal of Integrated Supply Management, 12(4), 285-308. https://doi.org/10.1504/IJISM.2019.103170

Lyngstadaas, H., \& Berg, T. (2016). Working capital management: evidence from Norway. International Journal of Managerial Finance, 12(3), 295-313.

Lyroudi, K., \& McCarty, D. (1993). An empirical investigation of the cash conversion cycle of small business firms. Journal of Small Business Finance, 2(2), 139-161.

Masri, H., \& Abdulla, Y. (2018). A multiple objective stochastic programming model for working capital management. Technological Forecasting and Social Change, 131, 141-146

Mohamad, N. E. A. B., \& Saad, N. B. M. (2010). Working capital management: The effect of market valuation and profitability in Malaysia. International Journal of Business and Management, 5(11), 140.

Moss, J. D., \& Stine, B. (1993). Cash conversion cycle and firm size: a study of retail firms. Managerial Finance, 19(8), 25-34.

Mulyono, S., Djumahir, D., \& Ratnawati, K. (2018). The effect of capital working management on the profitability. Jurnal Keuangan dan Perbankan, 22(1), 94-102.

Mun, S. G., \& Jang, S. S. (2015). Working capital, cash holding, and profitability of restaurant firms. International Journal of Hospitality Management, 48, 1-11.

Opler, T., Pinkowitz, L., Stulz, R., \& Williamson, R. (1999). The determinants and implications of corporate cash holdings. Journal of Financial Economics, 52(1), 3-46.

Pais, M. A., \& Gama, P. M. (2015). Working capital management and SMEs profitability: Portuguese evidence. International Journal of Managerial Finance, 11(3), 341-358.

Panda, A. K., \& Nanda, S. (2018). Working capital financing and corporate profitability of Indian manufacturing firms. Management Decision, 56(2), 441-457.

Pirttilä, M., Virolainen, V. M., Lind, L., \& Kärri, T. (2019). Working capital management in the Russian automotive industry supply chain. International Journal of Production Economics. https://doi.org/10.1016/j.ijpe.2019.08.009

Raheman, A., \& Nasr, M. (2007). Working Capital Management and Profitability - Case of Pakistani Firms. International Review of Business Research Papers, 3(1), 279-300.

Ramiah, V., Zhao, Y., \& Moosa, I. (2014). Working capital management during the global financial crisis: the Australian experience. Qualitative Research in Financial Markets, 6(3), 332-351.

Shin, H. H., \& Soenen, L. (1998). Efficiency of Working Capital and Corporate Profitability. Financial Practice and Education, 8, 37-45. 


\section{Macrothink}

International Journal of Accounting and Financial Reporting ISSN 2162-3082 2020, Vol. 10, No. 1

Shrivastava, A., Kumar, N., \& Kumar, P. (2017). Bayesian analysis of working capital management on corporate profitability: evidence from India. Journal of Economic Studies, 44(4), 568-584.

Singh, H. P., Kumar, S., \& Colombage, S. (2017). Working capital management and firm profitability: a meta-analysis. Qualitative Research in Financial Markets, 9(1), 34-47.

Tran, H., Abbott, M., \& Jin Yap, C. (2017). How does working capital management affect the profitability of Vietnamese small-and medium-sized enterprises?. Journal of Small Business and Enterprise Development, 24(1), 2-11.

\section{Copyright Disclaimer}

Copyright for this article is retained by the author(s), with first publication rights granted to the journal.

This is an open-access article distributed under the terms and conditions of the Creative Commons Attribution license (http://creativecommons.org/licenses/by/4.0/) 